\title{
Application analysis of ET control of water resources management in mountain counties
}

\author{
Ming-Qi Chang, Yue Wang, Lei Xu and Yan-Li Fan \\ China Irrigation and Drainage Development Center \\ Beijing, 100054, China \\ E-mail:cmq93@163.com
}

\begin{abstract}
Firstly, according to water resource management interactive model based on ET, calculation methods of present ET, target ET and subtractive ET and realization approach of ET control in mountain counties have been put forward. Secondly, Linxian has been taken as an example to calculate present ET by RS monitoring method, target ET by top-down approach, and do township apportionment by SWAT model. Target ET in the year of 2020 and 2030 has been forecasted and subtractive ET has been calculated. Thirdly, aimed at ET reduction value, water saving potential of Linxian has been analyzed, approaches and suggestions for water resources efficient utilization has been proposed, references and experiences of ET control application in the water resources management for mountain counties has been provided.
\end{abstract}

Keywords: ET control; Mountain Counties; Water Resources Management

\section{Introduction}

In the past, to achieve water control, water resource management mainly relays on total usage control, quota control, and efficiency improvement, rather than on water resource consumption control. In the hydrological cycle of rainfall, water runoff, evaporation, and other factors, only ET is the true indicator of water resource consumption, current researches are mostly focused on plain regions, and ET based water resource management in mountain regions have not been extensively studied[1-5]. In this paper, the use of ET based water resource management interactive model is proposed, using LinXian County as an example

\section{ET Based Water Resource Management Interactive Model}

ET based water resource management interactive model, through ET control, confirms water resource allocation plan and guides water usage reduction actions. In county scale, the model can be divided into county and township levels, and includes ET calculation, current ET assessment, subtractive ET, and ET control four parts, the specific model is shown in Figure 1. 


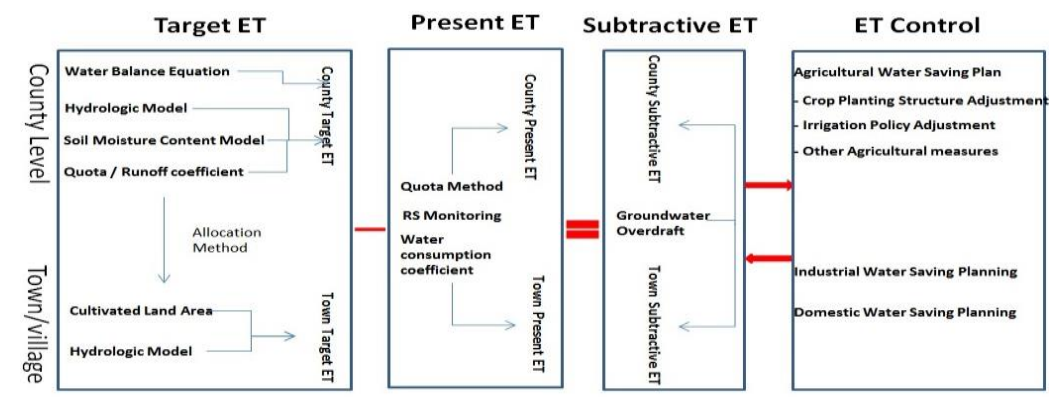

Fig. 1. ET based water resource management interactive model.

Target ET is the amount of water consumption that is required to support sustainable economic development in a particular development stage of the river basins, calculated based on water resource condition and must support sustainable virtuous circle of ecological environment, and its components include (1)vegetation transpiration, crop evapotranspiration, and soil and water surface evaporation. (2)consumption of water that got solidified and trapped in agriculture and industrial products during manufacture, then transferred out of the region. Present ET refers to the total of actual evapotranspiration in the region. Subtractive ET, which is used for ET control, equals to the difference between Target ET and Present ET. To close the gap, ET control reduces subtractive ET mainly by developing effective water usage plan. ET control includes three aspects: agricultural water saving, industrial water saving, and domestic water saving; agricultural water saving includes: adjust planting structure, adjust irrigation system, and develop water-saving irrigation measures; industrial water saving includes: adjust construction of high water consumption and high pollution industrial projects, limit water usage allowance and promote water-saving equipment, improve water reuse rate, promote recycling of waste water, and etc; urban living water saving includes: determine water usage allowance, adjust water price, promote water-saving equipment, improve urban pipelines, and promote sewage treatment technology, and etc.

\section{Mountain Region ET Calculation and Distribution}

\subsection{Present ET calculation}

Present ET monitoring and calculation methods are many, currently applied methods include: Water consumption coefficient method, quota method, and RS monitoring method. In mountain regions, ET and rainfall control are difficult and very uneven; therefore, present ET calculation needs to consider the geography and land features when obtaining actual ET, and at the same time, consider industrial water consumption and domestic water consumption when 
obtaining comprehensive present ET.

\subsection{Target ET calculation and distribution}

\subsubsection{Target ET calculation}

Currently, there are two main ways to calculate target ET: bottom-top and top-bottom. Bottom-top method, basing on principles of water cycle, takes the whole point of view and calculates Target ET through water balance equation; Top-bottom method, considers different types of land use and calculates each type's target ET separately, then sum up weighted values to obtain comprehensive target ET. To calculate target ET in mountain region, top-down method is preferred.

\subsubsection{Target ET distribution}

In sub areas, Target ET allocation method mainly includes: cultivated land use method and hydrological simulation method. Cultivated land use method is suitable for area with high agriculture water usage and relative little data on file; it can provide a rough target ET distribution through cultivated land area analysis. Hydrological simulation method, mainly uses hydrological model to determine water balance parameters in different sub areas, and then calculates target ET of different sub areas. Due to small cultivated land area in mountain region, cultivated land use area method can be ineffective without the support of SWAT model, which can calculate water yield in different towns and villages, and confirm it with water balance.

(1)The principle of SWAT model

SWAT model hydrological process formula:

$$
\mathrm{Q}=\frac{(p-0.2 s)^{2}}{p+0.8 s}
$$

$\boldsymbol{Q}$ - Represents the actual runoff or effective rainfall;

$\boldsymbol{p}$ - Represents the sum of the loss of runoff and initial retention amount, which is the amount of rainfall in the corresponding area;

$\boldsymbol{s}$ - Represents the maximum possible retention, which depends on the soil infiltration rate and soil water storage capacity, $\mathbf{S}=\frac{25400}{C N}-254, \mathrm{CN}$ can be obtained using SCS model by calculating combinations of different soil types, land use types, and vegetation coverage.

Peak flow calculation of SWAT (with a modified inference method), for example: 


$$
q_{\text {peak }}=\frac{\text { CiArea }}{3.6}
$$

$\boldsymbol{q}_{\text {peak }}$ - Peak surface runoff;

C - Runoff coefficient;

$i$ - Rainfall intensity;

Area - Sub basin area.

(2)The establishment of SWAT model database

The basic data required for the preparation of the SWAT model include: Basin DEM (digital and other high model) map (digital), land use map (digital), soil type map (digital), vegetation type map (digital), weather stations, other data, and etc.

(3)SWAT results and calibration

1) Basin River network extraction and basin subdivision

SWAT model depends on DEM for terrain analysis to determine flow direction of each cell on the grid; contrasts flow relation with adjacent cells, defines basin catchment area and watershed, and then determines basin river network and sub basins.

2) Basin hydrological response unit (HRU) Division

Organize soil, land use types, slope with same characteristic in sub basin into a HRU. SWAT model provides two ways to consolidate HRU. 1. Combines the largest land use area and soil type to form a HRU in each sub basin; 2. Multiple hydrologic response unit method, sets the minimum percentage threshold for land use area and soil types, and then merges cells with same hydrologic characteristic into one category of HRU. Model first calculates each HRU separately, and then sums up all HRU runoff, the amount, which represents the water flow value of the sub basin.

\subsection{Subtractive ET Calculation}

For regions with zero or near zero water resources, subtractive ET can be obtained directly by taking the difference of Target ET and Present ET. For overdraft area (groundwater), the overdraft (groundwater) amount should be allocated to subtractive ET of different areas according to overdraft intensity and recovery possibility.

\subsection{ET control implementation}

Due to limited irrigation area in mountain region, ET control will primarily focus on industrial water usage and domestic water usage. Agriculture measures comprise drought resistant crops, irrigation methods, and some policy adjustment. At the same time, because of above average evaporation in 
mountain area and concentrated summer rainfall, both rainwater collection and increase of interception projects can improve available water resource and ET control in mountain region.

\section{Linxian ET Calculation}

Linxian County is located in the middle range of the Yellow River, west side of Lvliang mountain of the Loess Plateau, altitude increases from southwest to northeast, highest point $1923 \mathrm{~m}$, lowest point $673.6 \mathrm{~m}$, mountain area accounts for more than $95 \%$. Rivers in the territory are part of Yellow River basin, have clear characteristics of Summer Rain River and Mountain Region River.

\subsection{LinXian present ET calculation}

Base on land use types breakdown of LinXian County, estimate the area of different types of land in the county, then combine with actual (measured) ET to calculate present ET in different regions.

Due to the lack of monitoring ET data for different land use types, for calculation, this paper uses ET data from Sanchuanhe River Basin where land features and basic conditions are similar to those of LinXian County According to research[.6,7], after comprehensive analysis and calculation, LinXian County's actual present ET equals to $498.69 \mathrm{~mm}$, water consumption was calculated to be $4.08 \mathrm{~mm}$, and LinXian County's Present comprehensive ET equals to $502.77 \mathrm{~mm}$, the sum of Present actual ET and unrecyclable water consumption amount. See Table 1 
Table 1. Present ET, Domestic Water Consumption, and Comprehensive Present ET (Towns and villages)

\begin{tabular}{|c|c|c|c|c|c|c|c|c|c|}
\hline \multirow{2}{*}{ Towns } & \multicolumn{2}{|c|}{$\begin{array}{c}\text { Target } \\
\text { ET }\end{array}$} & \multicolumn{2}{|c|}{$\begin{array}{c}\text { Subtractive } \\
\text { ET }\end{array}$} & \multirow{2}{*}{ Towns } & \multicolumn{2}{|c|}{ Target ET } & \multicolumn{2}{|c|}{ Subtractive ET } \\
\hline & 2020 & 2030 & 2020 & 2030 & & 2020 & 2030 & 2020 & 2030 \\
\hline Baiwen Zhen & 534.49 & 540.91 & 9.19 & 8.24 & $\begin{array}{c}\text { Linquan } \\
\text { Zhen }\end{array}$ & 533.27 & 542.61 & 37.94 & 47.79 \\
\hline $\begin{array}{c}\text { Cheng } \\
\text { zhuang } \\
\text { Zhen }\end{array}$ & 518.01 & 521.69 & & & $\begin{array}{l}\text { Mugua } \\
\text { ping } \\
\text { Xiang }\end{array}$ & 509.4 & 510.7 & & \\
\hline $\begin{array}{l}\text { Tuban } \\
\text { Zhen }\end{array}$ & 534.52 & 534.52 & & & $\begin{array}{l}\text { Anye } \\
\text { Xiang }\end{array}$ & 556.84 & 568.59 & 18.29 & 17.23 \\
\hline $\begin{array}{l}\text { Kehu } \\
\text { Zhen }\end{array}$ & 497.45 & 497.45 & & 9.88 & $\begin{array}{l}\text { Yuping } \\
\text { Xiang }\end{array}$ & 512 & 512 & 12.33 & 12.66 \\
\hline $\begin{array}{c}\text { Sanjiao } \\
\text { Zhen }\end{array}$ & 554.16 & 564.98 & 46.62 & 46.39 & \begin{tabular}{|c|} 
Qingliangsi \\
Xiang
\end{tabular} & 495 & 495 & 48.89 & 49.08 \\
\hline $\begin{array}{l}\text { Cuanshuitou } \\
\text { Zhen }\end{array}$ & 529.59 & 541.33 & 58.88 & 63.21 & \begin{tabular}{|c|} 
Shibaitou \\
Xiang
\end{tabular} & 495 & 495 & 79.23 & 79.48 \\
\hline $\begin{array}{l}\text { Linjiaping } \\
\text { Zhen }\end{array}$ & 563.4 & 579.02 & 42.9 & 40.78 & $\begin{array}{l}\text { Leijiaqi } \\
\text { Xiang }\end{array}$ & 475 & 475 & 40.17 & 40.3 \\
\hline $\begin{array}{c}\text { Zhaoxian } \\
\text { Zhen }\end{array}$ & 508 & 508 & 75.66 & 78.21 & $\begin{array}{l}\text { Babao } \\
\text { Xiang }\end{array}$ & 510.93 & 510.93 & 20.43 & 32.29 \\
\hline $\begin{array}{l}\text { Qikou } \\
\text { Zhen }\end{array}$ & 611.8 & 618.76 & & & $\begin{array}{l}\text { Dayu } \\
\text { Xiang }\end{array}$ & 537.6 & 546.57 & 64.02 & 63.07 \\
\hline $\begin{array}{c}\text { Liujiahui } \\
\text { Zhen }\end{array}$ & 510 & 510 & 81.05 & 81.5 & $\begin{array}{c}\text { Chegan } \\
\text { Xiang }\end{array}$ & 514.66 & 518.28 & 57.23 & 57.11 \\
\hline $\begin{array}{l}\text { Congluoyu } \\
\text { Zhen }\end{array}$ & 631.52 & 631.52 & & & $\begin{array}{c}\text { Anjia } \\
\text { zhuang } \\
\text { Xiang }\end{array}$ & 502 & 502 & 75.96 & 75.96 \\
\hline Quyu Zhen & 558.88 & 558.88 & & 2.84 & Total & 12193.52 & 12283.74 & 768.79 & 806.02 \\
\hline
\end{tabular}

\subsection{LinXian target ET Calculation and distribution}

Top-bottom method and regional characteristic was combine to form LinXian County target ET calculation formula

$$
\text { Target } E T=E T_{R}+W_{C}=P+W_{\text {in }}+W_{D^{-}} W_{\text {out }}-\Delta W
$$

$E T_{R}$--Vegetation transpiration, soil or water surface evaporation;

$W_{C}$-- Consumption of water that got solidified and trapped in agriculture and industrial products during manufacture, then transferred out of the region;

$\mathrm{P}$ - average annual precipitation;

$W_{\text {in }}$-- Inflow/water entry amount;

$W_{D^{--}}$Water that got solidified and trapped in agriculture and industrial products during manufacture, then transferred into the region;

$W_{\text {ou } t^{--}} \quad$ Runoff/outflow amount;

$\triangle W$-- Average of change of groundwater amount.

LinXian County's target ET for 2012, 2020, and 2030 were calculated to be 
$485.78 \mathrm{~mm}, 516.15 \mathrm{~mm}$, and $522.32 \mathrm{~mm}$.

It is difficult to apply the allocation method developed for plains area. Therefore, SWAT model is needed to determine the allocation of target ET for each town and village.

According to Basin River network extraction and basin subdivision process, the region was divided into 34 sub basins, and divided into 268 hydrological response units. Measured hydrological data from Lin Ping and Yang Jia Po from 1957 to 1959 were used for calibration and validation. See Figure 2 and Figure 2 and Table 2.

Extraction results

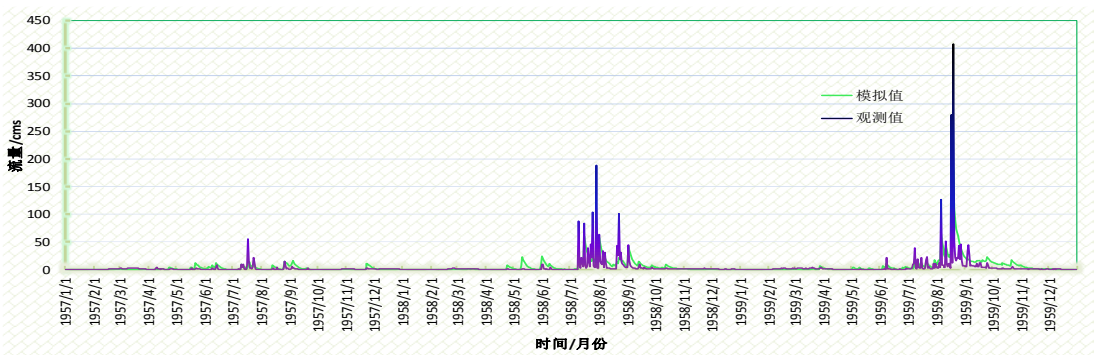

Fig. 2. Measured vs. Simulated flow comparison during the calibration period (Qiushui River Linjiaping station)

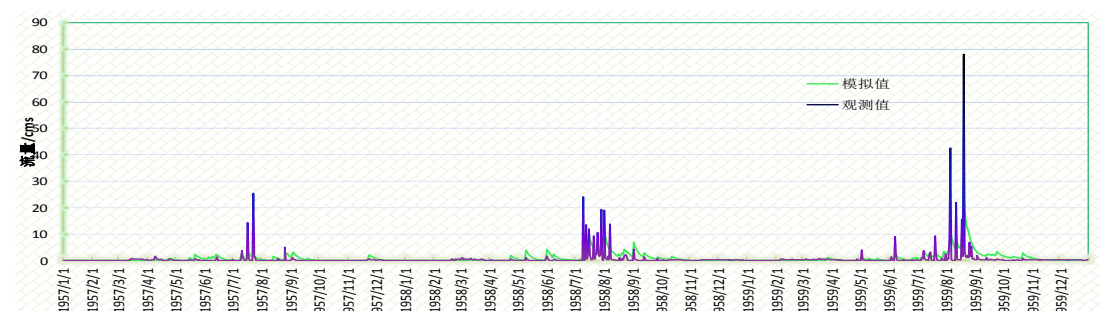

Fig. 3. Measured vs. Simulated flow comparison during the calibration period (Qingliangsi River Yangjiapo station).

\subsection{Calculation for LinXian subtractive ET}

Subtractive ET is the difference between Present Comprehensive ET and Target ET. 2012, 2020, and 2030 subtractive ET are $16.99 \mathrm{~mm}, 13.2 \mathrm{~mm}$, and $15.01 \mathrm{~mm}$. Subtractive ET for each town and village can be calculated using the same method. 
Table 2. 2020, 2030Target ET \& Subtractive ET (Towns and Villages) unit:mm.

\begin{tabular}{|c|c|c|c|c|c|c|c|}
\hline \multirow[t]{2}{*}{ Towns } & $\begin{array}{c}\text { Present } \\
\text { ET }\end{array}$ & $\begin{array}{c}\text { Domestic } \\
\text { Water } \\
\text { Consumption }\end{array}$ & $\begin{array}{c}\text { Compreh } \\
\text { ensive }\end{array}$ & \multirow[t]{2}{*}{ Town } & Present ET & $\begin{array}{c}\text { Domestic } \\
\text { Water } \\
\text { Consumption }\end{array}$ & $\begin{array}{l}\text { Compre } \\
\text { hensive }\end{array}$ \\
\hline & $(\mathrm{mm})$ & $\left(10,000 \mathrm{~m}^{3}\right)$ & ET(mm) & & $(\mathrm{mm})$ & $\left(10,000 \mathrm{~m}^{3}\right)$ & $\mathrm{ET}(\mathrm{mm})$ \\
\hline $\begin{array}{l}\text { Babao } \\
\text { Xiang } \\
\end{array}$ & 494.37 & 10.76 & 505.13 & \begin{tabular}{|c|}
$\begin{array}{c}\text { Zhaoxian } \\
\text { Zhen }\end{array}$ \\
\end{tabular} & 562.39 & 12.07 & 574.46 \\
\hline Kehu Zhen & 461.69 & 9.6 & 471.29 & $\begin{array}{l}\text { Quyu } \\
\text { Zhen }\end{array}$ & 499.96 & 20.61 & 520.58 \\
\hline $\begin{array}{l}\text { Leijiaqi } \\
\text { Xiang }\end{array}$ & 492.54 & 13.39 & 505.93 & $\begin{array}{l}\text { Muguaping } \\
\text { Xiang }\end{array}$ & 482.06 & 13.43 & 495.49 \\
\hline $\begin{array}{l}\text { Sanjiao } \\
\text { Zhen }\end{array}$ & 530.65 & 43.79 & 574.44 & $\begin{array}{c}\text { Linjiaping } \\
\text { Zhen }\end{array}$ & 554.45 & 22.26 & 576.72 \\
\hline $\begin{array}{l}\text { Congluoyu } \\
\text { Zhen }\end{array}$ & 457.82 & 13.8 & 471.62 & $\begin{array}{c}\text { Cuanshuitou } \\
\text { Zhen }\end{array}$ & 550.51 & 13.85 & 564.36 \\
\hline $\begin{array}{c}\text { Linquan } \\
\text { Zhen }\end{array}$ & 461.67 & 66.86 & 528.54 & $\begin{array}{l}\text { Yuping } \\
\text { Xiang }\end{array}$ & 503.14 & 14.3 & 517.44 \\
\hline $\begin{array}{l}\text { Tuban } \\
\text { Zhen }\end{array}$ & 446.41 & 18 & 464.41 & $\begin{array}{c}\text { Shibaitou } \\
\text { Xiang }\end{array}$ & 551.39 & 16.15 & 567.54 \\
\hline $\begin{array}{c}\text { Liujiahui } \\
\text { Zhen }\end{array}$ & 561.03 & 23.68 & 584.71 & $\begin{array}{l}\text { Qikou } \\
\text { Zhen }\end{array}$ & 484.31 & 24.4 & 508.71 \\
\hline $\begin{array}{c}\text { Cheng } \\
\text { zhuang } \\
\text { goulin } \\
\text { Chang }\end{array}$ & 378.82 & 0 & 378.82 & $\begin{array}{l}\text { Zijinshanlin } \\
\text { Chang }\end{array}$ & 432.33 & 0 & 432.33 \\
\hline $\begin{array}{c}\text { Cheng } \\
\text { zhuang } \\
\text { Zhen }\end{array}$ & 469.1 & 20.49 & 489.59 & $\begin{array}{l}\text { Chegan } \\
\text { Xiang }\end{array}$ & 549.59 & 11.86 & 561.45 \\
\hline $\begin{array}{l}\text { Dayu } \\
\text { Xiang }\end{array}$ & 549.67 & 30.9 & 580.57 & $\begin{array}{l}\text { Qingliangsi } \\
\text { Xiang }\end{array}$ & 523.74 & 12.11 & 535.85 \\
\hline $\begin{array}{l}\text { Anye } \\
\text { Xiang }\end{array}$ & 532.9 & 17.7 & 550.61 & $\begin{array}{l}\text { Baiwen } \\
\text { Zhen }\end{array}$ & 489.09 & 33.05 & 522.14 \\
\hline $\begin{array}{c}\text { Anjia } \\
\text { zhuang } \\
\text { Xiang }\end{array}$ & 558.22 & 14.46 & 572.68 & Total & 12577.85 & 477.52 & 13055.41 \\
\hline
\end{tabular}

\section{LinXian ET Control Analysis and Conclusion}

LinXian County industrial water usage accounted for $54.1 \%$ of total water usage, agriculture water usage accounted for $28.6 \%$, domestic water usage and other water usage accounted for only 17.3\%. LinXian County's 2020 and 2030 industrial water saving potential are calculated to be 16.7817 million $\mathrm{m} 3$ and 18.8485 million m3, LinXian County's 2020 and 2030 domestic water saving potential are calculated to be $456,000 \mathrm{~m} 3$ and $920,000 \mathrm{~m} 3$ agricultural water-saving potential is calculated to be 22.074 million $\mathrm{m} 3$ for 2020 and 30.772 million m3 for 2030. LinXian's target subtractive ET for 2020 is $13.2 \mathrm{~mm}$ (industrial $5.63 \mathrm{~mm}$, agricultural $45.6 \mathrm{~mm}$, domestic $0.15 \mathrm{~mm}$ ); target subtractive ET for 2030 is $16.97 \mathrm{~mm}$ (industrial $6.33 \mathrm{~mm}$, agricultural $10.33 \mathrm{~mm}$, domestic 
$0.31 \mathrm{~mm})$.

LinXian County central economic zone, Muguaping industrial economic zone, Sanjiao mining economic zone, and qiushui river irrigation area are county's key economic development regions and all facing grim water supply situation. To solve this issue and meet the needs of future economic development in key areas, a feasible water resource allocation plan must consider the following: future economic development direction, water conservancy project construction scale, layout, and implementation.

ET based water resource management in mountain regions have not been extensively studied. It can be based on ET based integrated water resources management model framework, using LinXian county calculation as an example, analyzing LinXian's ET control target and water-saving potential and methods to use water resources efficiently, and provide basis for the formulation of government policy and planning.

\section{References}

1. Wei Liang, Yongchao Liu, Haixin Shen. Guantao County ET Management Water Resource Allocation Applications [J]. Hai River Water Resources,2007,(2):52-54.(in Chinese)

2. Dayong Qin, Jinyan Lv, Jiahong Liu, Mingna Wang, Theory and Calculation methods of Regional Target ET[J]. Science Bulletin, 2008, (19):2384-2390. (in Chinese)

3. Jiahong Liu, Dayong Qin, Mingna Wang, Xuefeng Sang, Jinyan Lv, Ruimei Zhang, Theory and Calculation methods of Regional Target ET Applications[J].China Science,2009,39(2):318-323. (in Chinese)

4. Yunzhong Jiang, Hongli Zhao, Zhiguo Gan, Minggang Hu, ET based Water Resources Allocation [J]. Journal of Hydraulic Engineering, 2008, 39(6):720- 725. (in Chinese)

5. Fang Zhang, Jianxin Xu, Yichang Wei, Caifeng Yuan, Hongjun Lei, Zhihong Qie, ET based County Water Resources Allocation Research[J]. Journal of Irrigation and Drainage, 2011, 30(2):107-110. (in Chinese)

6. Yan Jin. Study on the impact of human activities on runoff changes in Sanchuanhe River Basin of the Loess Plateau [D].Zhengzhou: : North China Institute of Water Conservancy and Hydroelectric Power,2005. (in Chinese)

7. Hao Wang, Evaluation Method of River Basin Water Resources under changing environment [M].Beijing: China Water Conservancy and Hydropower Publishing House.2005. (in Chinese) 